\title{
THE EXISTENCE OF SHIVA IN LONTAR PURWAKA BHUMI
}

\author{
PUTU SABDA JAYENDRA ${ }^{16}$
}

\begin{abstract}
The Hinduism in Bali is dominantly influenced by Shiva Siddhanta that regards Lord Siwa as the ultimate reality. This is, of course, different from the concept of Hinduism in India which mostly influenced by the Upanishads that regard Brahman as the supreme reality. The existence of Shiva as the highest and the ultimate amongst the gods can be found in most of the lontars in Bali, one of them is Lontar Purwaka Bhumi
\end{abstract}

\section{INTRODUCTION}

Literatures have so much value in them which could help human beings to develop their knowledge and morality. Literature which guides readers to enter the prismatic territory, is one with its literary plot directed to enter into an area of self identity (Jatha, 1984: 13). Thus, the narrative literature will invite readers to dissolve and find the truth within themselves, speak in themselves and thus their humanity will be touched, which rises man's consciousness of the nature of wisdom.

Particularly lontars in Bali, overall had a very useful value for the spiritual progress of human beings. Because by its plot, classical literatures follow purwa dresta or kuna dresta, these lontars have prismatic plots that leads to wisdom. Thus the essence of literature that goes along with it, will be able to be easily understood. For literature itself leads to wisdom. Similarly, with the presence of educational value in Hinduism that led to the vidya dadati vinayam, that education was essentially makes a person more wise and prudent . Of course this leads to a concept, in which man must be aware of himself and his relationship with God.

Balinese Hindus, tend to worship God in the form of Saguna Brahman which has form, attributes and properties just like material creature. Therefore, the Lord in this state, more popularly revered than the Nirguna Brahman, that is without form and nature. Literatures or lontars in Bali , mostly have the doctrine of God in the form of Shiva, because historically, when Maharishi Agastya came, he brought and spread the concept of God as Shiva.

There are so many lontars belong to Shiwaist sect. They all have similar value with other lontars on philosophy and theology, one of them is Lontar Purwaka Bhumi, which explains the existence of Siwa based on the local wisdom of Bali. Lord Shiva, who is worshiped as the supreme reality in Bali is different from the concept of Hindu in India, where the ultimate reality is Brahman . It is interesting to study and to understand the philosophy of Shiva in greater depth based on the local wisdom of Hinduism in Bali.

\footnotetext{
${ }^{16}$ Putu Sabda Jayendra, S.Pd.H., M.Pd.H. is a student of Doctoral Studies Program (S-3) Religious Studies, Post Graduate Program of IHDN Denpasar.
} 


\section{DISCUSSION}

\subsection{Shiva-Nama In Purwaka Bhumi}

Hinduism in Indonesia and in India certainly has different view on Lord Shiva. However, when answering question on the actual position of Lord Siwa, certainly not everyone can give proper argument. Because His existence is abstract and universal. There are many names known to refer to Lord Shiva, all depending on the place and on the situation. In Bali, He is known as Bhatara Shiva, Sanghyang Shiva, Sanghyang Pramesti Guru, Bhatara Guru, and so forth. Yet he is the one and only, wise men call Him by many names.

When viewed from the epistemology of the name of Shiva, the word Shiva itself means One who gives luck (kerahayuan), the good-natured, friendly, forgiving, fun, giving lots of hope, calm, happy, and the like. The name of Shiva has the power to eliminate all ignorance.

Lord Shiva is one of the three main deities (Tri Murti) in Hinduism, two of which are Lord Brahma and Lord Vishnu. In the Tri Murti, Lord Brahma is the creator (uttpeti) and Lord Vishnu as the preserver (sthiti). While Lord Shiva is the god of the fuser (pralina), His role is to fuse everything that is outdated and not worthy of being in the mortal world again so it must be returned to its origin. Shiva has nother names, such as Jagatpati, Nilakantha, Parameswara, Rudra, Trinetra. His consorts are Goddess Parvati, Uma, Durga, Goddess Kali.

Lord Shiva is also one of the main gods of Nawasanga, that is the nine gods or manifestation of Ida Sang Hyang Widhi Wasa to maintain or to control the nine directions. Lord Shiva in Pengider Dewata Nawasanga is positioned in the middle or intermediate, armed with Padma, has five colors, His letters are $(I)$ and $(Y a)$ and has an ox named Nandini as His vehicle.

When talking more about the existence of Lord Shiva, certainly will not be able to restrict His majesty. He is wyapi - wyapaka which is everywhere and permeates all things, $\mathrm{He}$ is immanent (present everywhere) and transcendent (beyond the human mind and the senses), he also is the Personal God and Impersonal God, he also is Cadhu Sakti (Prabhu Sakti, Wibhu Sakti, Jnana Sakti, and Kriya Sakti ).

In the Lontar Purwaka Bhumi, it is said that Lord Shiva is the beginning of all things. As stated in Linga Purana that Lord Brahma actually appeared from the right waist of Lord Shiva and Lord Vishnu appeared from the left waist of Lord Shiva. Indeed Brahma, Vishnu and Shiva are one, yet diverged because of the three tasks, that is Brahma as the creator, Vishnu as the preserver and Shiva as the fuser.

In the Lontar Purwaka Bhumi, the creation of the universe from nothingness or sunia is explained. Only Sanghyang Sunia lived alone without anyone to speak to. Due to the grandeur of Sanghyang Sunia, Bhatari Uma, Bhatara Iswara, Lord Brahma, Lord Mahadeva, Lord Vishnu and Shiva are eventually created. Sanghyang Sunia ordered His six sons to create the universe, but four of them refused to do so because they did not have the power. Bhatari Uma and Lord Shiva are the ones that obeyed the command of Sanghyang Sunia. That time Bhatara Shiva is referred to as Bhatara Guru, because he became the teacher (guru) of all Gods. Beside that, Lord Shiva and goddess Uma regarded as Ardhanareswari. 
In the Shiva Sahasra Nama, various names of Lord Shiva is mentioned. Such as Iswara, Mahadeva, Guru, and the rest mentioned in the Purwaka Bhumi are the feminine forms of Lord Shiva. In other words, sometimes, The Sakti of Siva himself expressed with different names and forms. Sharma (2009: 55$)$ states that Shiva is the central form of the material ruler who is most dear by his devotee, thus Lord Shiva himself was known by the name of Asutosha. Literally meaning the easiest to be pleased. In the Purwaka Bhumi, Lord Shiva is also referred as The Guru, Mahadeva, Iswara. So if we look closer, we will find the following definitions.

1. Iswara. Derived from the Sanskrit language "Isa" which means "one". Then "Wara" that meet the definition of "Compliance", "have", "Ruler". It can be concluded that Iswara is the single personality who has full power.

2. Mahadeva. Derived from the Sanskrit language 'maha' which means huge. The word "Dewa" or uric word "div" means light. So in this case, Shiva expressed as God/Dewata, or the most powerful god. Although from the description of some Puranas, the king of the gods is Indra, but in terms of Purwaka Bhumi, Lord Shiva is the king of all gods.

3. Mahaguru or Jagatguru. In the Purwaka Bhumi it has different definition. The existence of Lord Shiva as a creator replaced the task of Lord Brahma as mentioned in Purana scriptures. Because in the Purwaka Bhumi it is stated that the creator is guru (initial and guiding), hence Lord Shiva was declared as Jagatguru, or Master of the universe.

So if we look carefully at the Pangider Bhuwana, like the god Sambhu, Maharudra, Sankara, Mahesora is nother names for Shiva. It was stated by the Siwa Nama. Here appears, that although the author of the Lontar Purwaka Bhumi is anonymous, but it looks like the author chopped off Shiva Sahasra Nama from Shiva Purana, originally derived from Bharatavarsa.

Siwa Namas that are most familiar with the material creation are written in the sargah part ( creation ) of the Puranas, and re-narrated on the Lontar Purwaka Bhumi. Those forms are then separated again in accordance with the capacity of the Gods as One who envelopes all aspects of life. It is not surprising, if the names of Siva is written as having distinct personal form from Shiva itself. But in reality, those names referred to his own personal form as Lord Shiva.

\subsection{The Existence of Lord Shiva in Purwaka Bumi}

Virtually all literary language in lontar Hinduism in Bali says that Lord Shiva is the highest. Hindu literatures that provide the teachings about the existence of Shiva as the highest is called Saivasiddhanta. The Saivasiddhanta teachings in Indonesia are mostly refers to the Upanishads (especially Svetasvatara Upanishads and minor Upanisads), the teachings of the Puranas, the teachings of Samkhya, Yoga, Vedanta and also the teachings of the book of Tantra. All are derived from the Vedic teachings, thus proving that Hinduism indeed refers to the Vedas.

Hinduism teaches that everything in this world comes from the God, are in God and return to God. As stated in the Mundaka Upanishad I.7, " like a spider making its webs by creating the yarn, like medicinal plants grow on eart, like the hair that grows on the head and body of people who live, thus the universe emerged from God". The above description said that in fact everything in this 
universe is created. God is the source of life and of energy of all this, and finally returned to Him all of this. Thus God is often referred to as Sangkan Paraning Dumadi, the origin of all living creatures.

Taittiriya Upanishads III.1 confirmed and has outlined about where all of this was originated, why these things become alive , where they go after returning, know that it is Brahman. In this case it is said that Brahman is Lord Shiva, He is the creator, preserver, and restore everything to Himself, he is also the origin of all that there is.

The concept of Ardhanareswari in Hinduism is known as the embodiment of two different properties become one. In the Purwaka Bhumi it is said that He ( Shiva ) in creating this world accompanied by His consort (Uma - Durga), from which came the concept of Ardhanareswari which means a merger between the two properties, namely men and women. Hinduism highly glorify this concept, even adoring to obtain safety and so forth . Ardhanareswari represents the union between Shiva with Uma as Rwabhineda as a symbol of balance.

The first appearance of Ardhanareswari was told in the Lontar Purwaka Bhumi which aims to purify his four brothers, such as: Iswara, Brahma, Mahadeva and Vishnu. In the lontar Purwaka Bhumi, it is stated that Sanghyang Sunia (God) commanded his six sons to create this world, namely goddess Uma, Iswara, Brahma, Vishnu, Shiva and Mahadeva. From all of them, four refused to obey because they feel lack of power to do so. Four of them, Iswara, Brahma, Vishnu, and Mahadewa are finally condemned to become Bhuta. Only Bhatari Uma and Sanghyang Shiva agreed to meet the demand. Once, the four brothers met Sanghyang Sunia. They, who had been doomed, begged to be purified and promised to always obey the command of Sanghyang Sunia. Both (Shiva and Uma) then met Sanghyang Sunia, communicating the request of his brothers, Sanghyang Sunia said:

Sang Hyang Widhi wisesa, lingira; "Sira sang hyang Siwa, arepa rama nira, anuddha mala sanak ira sadaya, anin sira kinon ingulun, arabya rabi laki nin Bhatari Uma, maka Ardhanareswari, maka gurune sanak ira sadaya, mapan sanak ira kawenang atemu lawan insun”.

Translation:

Sang Hyang Widhi Wisesa said " Sang Hyang Siwa, I will purify all your brother's filthiness, but thee have I commanded, to take goddess Uma, as Ardhanareswari, as their a master, because your brothers and sisters should not be met with Me.

Since then, the union of Lord Shiva - goddess Uma is called Ardhanareswari (Bhatara Guru), as the master of the gods . Because the four gods (Iswara, Brahma, Mahadeva, Vishnu) are not permitted to meet with Sanghyang Sunia, they can only communicate with Bhatara Guru, after his four brothers being purified to become gods and occupy their respective positions, and together they created and filled the world with inanimate and animate creatures, includes human beings.

Thus the concept of Ardhanareswari in Hindu mythology, like two different personalities but essentially one, that created the universe and its contents, 
including humans as the highest among other created beings without losing the grandeur of other creations. The concept of Ardhanareswari seems inherent in the people of the Hindu and has become their spirit. The third puja on kramaning sembah stated "Om nama dewa adhisthanaya, sarwa wyapi wai Siwaya, padmasana eka prathistaya, ardhanareswaryai nama namah" which means "Om. The god who resides on high ground, to Shiva which indeed is everywhere, the god who sits on a lotus as one place, to Ardhanareswari i salute". In this mantram is said that we adore Ardhanareswari to ask His blessings for safety, peace and so forth. Thus the concept of Ardhanareswari as a real form of Rwabhineda is inherent in human beings.

Yet when Lord Shiva is in the level of transcendence, He has the natures of na rupam (without form), na gandham (no smell), na sabdam (without sound), asparam (intangible), acintyam (unthinkable), anadi madhyantam (without beginning, no middle, no end, no limit), agatham (without shape) and others. It is also said that the appearance of Lord Shiva in creating the world was as Brahma when He created the world, as Vishnu when he maintains this world, as Rudra when he annihilate this world. Thus is his three forms (Tri Murti) yet in different names.

It is also stated that the whole universe emerged from of Lord Shiva, gone back to of Lord Shiva. Which means that all that exists is His, and He arranged everything. He also permeates all things, $\mathrm{He}$ is divine and unthinkable, $\mathrm{He}$ is like the sky, beyond the reach of the human mind and senses. He could be the Personal God as well as the Impersonal God. In this case also said that Lord Shiva is the creator of Purusa and followed by other elements such as Awyakta, Budhi, Ahamkara, Pancatanmatra and so on.

Furthermore, there are two universal elements exist in the universe, namely cetana and Acetana. Cetana is an element of consciousness, also called Siwatattwa, possessing the nature of "tutur prakasa". While Acetana is unconscious element called mayatattwa who is forgotfull in nature, tan pajnana, tan pacetana. Cetana or Siwatattwa has three planes, namely ParamaSiwatattwa, SadaSiwatattwa, and Atmikatattwa.

Parama Siwatattwa is Lord Shiva as formless, which is untouched by anything. Sada Siwatattwa is Lord Shiva who is already being touched by sarwajna, sarwakaryakarta, cadusakti, and jnanasakti. He is called Bhatara Adipramana, Bhatara Jagadnatha, Bhatara Karana, Bhatara Parameswara, Bhatara Guru, Bhatara Mahulun, and Bhatara Masawasitwa. Atmikatattwa is Sada Siwatattwa in the state of "utaprota" in mayatattwa (Acetana). 'Uta' means magically presents in mayatattwa like a fire that was in the wood, while prota means he who is like a brilliantly clear jewel in the mayatattwa. However, being wrapped by the red color of mayatattwa, He lost His sarwajna, cadusakti, sarwakaryakarta, and jnanasakti properties. Thus we can conclude that when He is in the level of Parama Siwatattwa, of Lord Shiva is untouched by Acetana. Being in Sada Siwatattwa level, Lord Shiva begins to be touched by Acetana. And when in Atmikatattwa levels, Lord Shiva is utaprota in Acetana..

Bhatara Shiva is immanent and transcendent in nature. Immanent means God is present everywhere while transcendent means overcoming the human mind and senses. Furthermore it is said that " Bhatara Shiva permeates all things, He is unseen, unthinkable, $\mathrm{He}$ is like the sky, beyond the reach of the mind and the 
senses". He is said to be immanent and transcendent because Lord Siva permeates everything, covering everything and is everywhere, He is able to be present in the mind and in the senses of human beings, yet the human mind and senses are not able to reach Him. Moreover, God is also said to be Acintya or unthinkable, Anadhi Madhya Antam which has no beginning, middle and end, Amita or infinite, Agatram that is formless and so forth.

\section{CLOSING}

Based on the above description,it can be concluded that Lord Shiva is expressed as Sanghyang Mahadewa in the Lontar Purwaka Bhumi. Which means the God of all gods. Occupies many forms, names and shapes in each material creation. He is called Iswara which means the Ruler of all things. Also referred to as Jagatguru, which means, that Lord Shiva is the creator of all material forms. In this context, getting an ameliorative, where Lord Shiva himself declared as the master, the elder, father and even the mother of the universe.

The existence of Lord Shiva in the Lontar Purwaka Bhumi, that Lord Shiva is the deity that has three dimensions as well as different names and forms. the level of pure transcendence, He declared Parama Shiva is non-dual. Formless, without attributes, without nature and without color. He was in this capacity, he, too, expressed as Sanghyang Sunia (God is in everything and is beyond everything in the same time). Then enter the dimensions of the transition between the immanent and the transcendent, the god Shiva is known by the name of Sanghyang Sada Shiva. Shiva occupies a position which has the power Asta Aiswarya. then when it created the world, then be at the level of the material dimension in full. In this context, he expressed as Sanghyang Shiva who own attributes, shapes, names and likeness.

\section{BIBLIOGRAPHY}

Jalaluddin, Haji. 2007. Filsafat Pendidikan Manusia, Filsafat, dan Pendidikan. Jogjakarta: Aruzz. Media Grup.

Jatha, Marku. 1984. Tinggalan Purbakala dan Sastra Kuna. Jakarta: PT. Pelangi Nusantara.

Jendra, I Wayan. 2009. Filsafat Ilmu Pengetahuan. Makalah disajikan Kuliah Pascasarjana IHDN Denpasar. 20 Desember 2009.

Maswinara, I Wayan. 1999. Dewa dan Dewi Hindu. Surabaya : Paramita.

Radhakrishnan, Sarvepali. 2011. diterjamahkan oleh Agus. S.Mantik. UpanisadUpanisad Utama. Surabaya: Paramita.

Radhakrishnan, Sarvepali.2011. Taittiriya Upanisad. Surabaya: Paramita.

\section{Papyrus}

Purwaka Bhumi. Terjemahan dan Lontar koleksi Nyoman Sukarta. Banjar KajaKangin, Beng - Gianyar. 